\title{
Digital Rights in Russia: Legal Regulation and Development Prospects
}

\author{
Khasimova L.N. ${ }^{1, *}$ Gumerova E.F. ${ }^{2}$ \\ ${ }^{1}$ Kazan Federal University, Naberezhnye Chelny Institute, Naberezhnye Chelny 423800, Russia \\ ${ }^{2}$ Kazan Innovative University named after V.G. Timiryasov (KIU), Naberezhnye Chelny Branch, Naberezhnye Chelny \\ 423800, Russia \\ *Corresponding author. Email: LNHasimova@kpfu.ru
}

\begin{abstract}
Digitalization is currently one of the main challenges for the development of the modern state. Technological progress in the Russian Federation is impossible without introducing the digital technologies in the economy and social spheres of life.

Based on the analysis of the current civil legislation of the Russian Federation and on the theoretical provisions related to the legal regulation of digital relations, the article analyzes the new Russian laws in the digital field. The article includes the research work of the statutory provisions as applied to the nature and content of digital rights, the civil law regime of digital rights. This work outlines the problems of digital rights regulation and the development prospects of laws in this area of relations. The conclusion defines the functions of a digital token (digital right) in the information system.

The article presents the authors' own views and includes an analysis of the theoretical studies of scientists in this field.
\end{abstract}

Keywords: digitalization, digital rights, property rights, token, utilitarian digital rights, legal regulation

\section{INTRODUCTION}

The digitalization process involves all countries in the world, as digitalization directly affects the country's competitiveness, ensures economic growth and improves the level and quality of life of the population. Digital economy is a system of economic relations in which economic activity is carried out using digital technologies. Countries with a developed digital economy use E-business to sell goods and services.

The Russian Federation Presidential Decree N 204 of May 7, 2018 "On National Goals and Strategic Objectives of the Development of the Russian Federation for the Period up to 2024" [1], defines the introduction support of digital technologies in the economy and social sectors as one of the top priorities. The adopted RF Digital Economy Program [2] emphasizes the need to create a relevant legal framework for economic relations in the new conditions of national development. The term "digital economy" was introduced by American professor Nicholas Negroponte in 1995 [3]. Since then, this term is used to define a new level of economic relations in a country based on digitalization. The Russian Federation gradually introduces digital technologies in many spheres: in banking operations, state and municipal services, transportation services, etc. E-business includes the transfer through the Internet ownership rights to goods or services. The undoubted advantages of e-business compared to traditional commodity circulation are cost reduction, decrease of demand for raw materials, the possibility to operate with various digital money, etc. However, unlike foreign countries, in the Russian Federation there is no appropriate legal regulation of relations in the digital sphere. This determines the relevance of the research topic.

\section{METHODS OF RESEARCH}

The relevance of studying the research topic taking into account the foregoing is predetermined by an attempt to comprehensively analyze the amendments in the Russian legislation in the field of digital rights.

The goal of the research work is to formulate a comprehensive understanding of the nature, content and legal regulation of digital rights as an object of civil rights of the Russian Federation.

The used methodology includes a comparative method, system analysis method, as well as private research methods, such as logical, analytical ones, etc.

Digital technologies such as artificial intelligence, Virtual Reality (VR), Augmented Reality (AR), Blockchain, and Cloud Computing have been created. 


\subsection{Principal directions to develop Russian laws on regulation of digital rights}

Russia does not hold leading positions regarding the legal regulation of this sphere of legal relations.

\subsection{Legal regulation of digital legal relations abroad}

Unlike domestic legislation, in many states there are a number of regulations governing the legal relations in the field of the digital economy.

For example, in France, such concepts as electronic trading and electronic commerce have been established at the legislative level [4].

The UK legal regulation of digital rights is carried out in accordance with the Regulation on electronic communications of infrastructure and services that ensure restriction of access to online pornography; Regulation on the protection of intellectual property in connection with the use of electronic communications; Regulation on the data exchange, etc. These provisions are included in the UK Digital Economy Act adopted in 2017 [5].

In February 2019, the Luxembourg Parliament passed amendments to the Securities Act according to which the legal status of securities issued using Blockchain technology is equal to the legal status of ordinary securities. Now it is possible to register and distribute securities using the distributed ledger technology [6].

In the United States, copyright in the digital space is regulated by Digital Millennium Copyright Act (DMCA) [7].

Abroad, it has been proposed to determine in regulatory acts the legal status of an electronic person (electronic personhood) as related to the intelligent robotic systems that make independent decisions [8, p.131]. It is important to note the relevance of the problems arising from the damage caused by artificial intelligence, robots and the need to develop a legal mechanism for imposing responsibility for such actions. For example, the problems of legal regulation of liability for accidents involving unmanned aerial vehicles and automobiles are studied by B. Casey [9].

European countries are engaged in development of CrowdFunding and CrowdInvesting, discussing the legal regulation of cross-border crowdfunding [10], and exploring the types and economic aspects of crowdfunding $[11,12,13]$.
Considering the main directions to develop Russian laws on regulation of digital legal relations, we can distinguish the following. V.A. Vaipan rightly remarks that "vague" details of the new digital economy development require proper legal implementation [14]. According to V.D. Zorkin, President of the Constitutional Court of the Russian Federation, a new digital reality has emerged, the new law is emerging that "regulates economic, political and social relations in the context of the world of numbers, big data, robots, artificial intelligence" [15]. Thus, in the age of rapid development of science and technology, it is simply necessary to create a legislative framework governing the relations in the field of digital technologies. M.V. Zhabotinsky states that "such methods of civil-law transactions have long been used like pressing buttons on a smartphone, sending SMS messages to confirm" [16, p. 40]. However, special regulation of these relations is still not stipulated by domestic legislation.

Therefore, timely development and adoption of federal laws aimed to develop the digital economy: determining the procedure for conducting civil law transactions in electronic form, regulating digital financial assets, attracting financial resources using digital technologies is a milestone event in the development of the country's economy and modern regulation of public relations [16, p. 40]. It is evident that due to the created information systems, the new rights emerged in cyberspace, which prompted the legislator to model a new object of civil rights based on a legal and technical approach.

Both for legal science in general and for the civil law specifically, formation of the legal framework governing the digital sphere and functioning of digital platforms are the priority areas of activity.

The Federal Law N 34-FZ of March 18, 2019 "On Amending Parts One, Two, and Article 1124 of Part Three of the Civil Code of the Russian Federation" will enter into force on October 1, 2019 [17]. This law amends Art. 128 of the Civil Code of the Russian Federation [18], according to which, along with the existing objects of civil rights, a new type appeared digital rights as property rights along with uncertified securities and non-cash money. Like other rights to civil rights objects, digital rights are subject to judicial protection.

\section{RESEARCH RESULTS}

\subsection{The concept and legal nature of digital rights}


Utilitarian digital rights are confirmed by digital certificates, which are non-issue-based uncertified securities with no par value.

The above amendments are designed to prepare the legal framework for the subsequent adoption of laws on digital financial assets, such as tokens, and cryptocurrency [12].

\subsection{Token as a method of fixing property rights}

The RF Civil Code establishes the digital right model in the form of a Blockchain token. Token (digital right) is a virtual unit operated by the Blockchain, representing a kind of digital code of the object and a digital key. Like a digital key, it recognizes an authorized person in an information system, and identifies him as a legitimate user or blocks the actions of an unauthorized person, preventing transactions with a token. The digital right owner is a person who is entitled to dispose of it in accordance with the rules of this information system, unless otherwise provided by the law.

An authorized user of the information system can perform operations (transactions) to pay for a token using cryptocurrency as a unit of settlement. In this regard, the following functions of a token in the information system can be identified:

- $\quad$ it can be a digital unit of price, for example, a participant's share in the authorized capital of a legal entity or the balance of an enterprise's property asset;

- it may be a value expression of an uncertificated security or other property object of civil right in a digital form.

L.Yu. Vasilevskaya rightly remarks that token has a digital currency unit function. "In this case, it is considered as a cryptocurrency token, i.e. as a payment instrument which can be exchanged for other digital objects, or which can be paid (through a transaction) for the provision in reality of a certain product, work or services. In its last meaning, token has the function of fulfilling a monetary obligation for goods already provided, work performed and services rendered, or it gives the right to receive such" [21].

The Federal Law N34-FZ does not contain any provisions on digital money that were originally stated in its draft. Cryptocurrency is also mentioned in the draft federal law "On Digital Financial Assets" [20] However, the draft law does not imply that cryptocurrency can become a legal payment instrument in the Russian Federation.

\subsection{Problems associated with the functioning of information systems}


electronic documents or other data in accordance with the rules of Art. 160 of the RF Civil Code. The new edition of Art. 493 of RF Civil Code confirms the electronic documents turnover.

In accordance with Art. 783.1 of the Civil Code of the Russian Federation [22], an agreement for delivery of information may provide for an obligation of the parties not to take actions during a certain period, because the information may be disclosed to third parties.

the data on the transfer of digital rights to the acquirer. This provision of the legislators gives rise to the problems associated with the final loss of access to digital rights, the need to enforce the right in electronic form, and the need to forcibly transfer it to another person.

Furthermore, it is necessary in this regard to clarify the moment of transfer of digital rights to the heir at the statutory level.

The analyzed amendments create the following problems associated with the functioning of Blockchain systems. There is no clear answer to the question: who controls the functioning of the system? Besides, no responsible person is determined for the accuracy of operations performed within the system. It is not clear who should be responsible for maintaining and processing the databases inside the information system.

\subsection{Legalization of transactions in the digital environment}

Since October 1, 2019, a new rule on the written form of a transaction has appeared in the Civil Code of the Russian Federation. A written transaction is considered to be observed also in the event that a person completes a transaction using electronic or other technical means allowing the contents of the transaction to be reproduced on a tangible medium, while the requirement for a signature is considered satisfied if any method was used to reliably identify the person expressing the will. The law, other legal acts and by agreement of the parties may provide for a special way to reliably determine the person who expresses his will. The amendments were related to Art. 160, 434, 454, 493, 494 of the Civil Code of the Russian Federation.

Accordingly, the adopted amendments are aimed at legalizing transactions in the digital environment. Thus, the new paragraph in Art. 309 of the RF Civil Code provides for the possibility of fulfilling obligations arising from the transaction without a separately expressed additional will of the parties through the use of information technologies defined by the terms of the transaction

In accordance with the new edition of paragraph 2 in Art. 434 of the Civil Code of the Russian Federation a written contract can be concluded by drawing up a single document, including an electronic one, signed by the parties, or by exchanging letters, telegrams,

\section{DEVELOPMENT PROSPECTS}

Development prospects for legal regulation of digital rights in Russia in the context of digitalization are associated with the further development of legislation in this area.

- It is necessary to finalize and adopt draft legislation developed in accordance with the Strategy for the Development of the Information Society in the Russian Federation for 2017-2030 [23]. It requires the development of a whole range of legislative acts governing the use of digital assets, the determination of the status of legal entities, amendments to the Civil Code of the Russian Federation, the Criminal Code of the Russian Federation and other applicable regulatory acts.

In 2018, the State Duma of the Federal Assembly of the Russian Federation adopted in the first reading the draft federal law No. 4190597 "On Digital Financial Assets" [20]. This bill is intended to regulate the relations arising from the issue, registration and circulation of digital rights. At the moment, the most controversial categories are excluded from it, such as cryptocurrency, mining, smart contract, token issuance procedures, etc. Such fundamental concepts for the digital economy as "cryptocurrency", "tokens", "mining", "Blockchain technology" remain so far outside the Russian legal field; cryptocurrency owners are deprived of the possibility of protecting their rights in administrative and judicial proceedings.

- Development prospects for the legal sphere in the digitalization context are associated with the need to determine the list of subjects and objects of digital legal relations to be fixed at the legislative level.

- An analysis of the legal regulation of digital legal relations shows that the issues of protecting an individual's right to information and information technology are relevant enough. Therefore, it is not enough just to provide opportunities for the rights implementation by the subjects in a legal relationship. The lawmakers needs to create legal tools and mechanisms for protecting the participants of digital legal relations from negative effects of digitalization. Cybercrime combatting needs a whole system of tools. 
We are witnessing the emergence of the regulation framework for legal relations in the field of digital rights and the digital economy in the Russian Federation. Of course, the adopted legislative amendments are the first step to the necessary transformations. They cannot adequately provide the necessary level of the arisen legal relations regulation, but they serve as a kind of foundation for the emerging legal relations and the basis for future transformations in the digital sphere.

Creation of new models and mechanisms for legal regulation of digital technology in the Russian Federation is generally targeted to provide socioeconomic protection, which will support consumer rights, and will ensure the transparency of business, the competition support and the security of confidential information.

We can say responsibly that we are on the verge of a completely different technological approach related to the digital revolution and the digital economy. Such a transition is predetermined by continuous scientific and technological progress, changes in the forms and models of economic organization, public administration mechanisms and the need for relevant legal regulation of the changes.

[5] Digital Economy Act 2017 URL:http://www.legislation.gov.uk/ukpga/2017/30/intr oduction.

[6] https://chd.lu/wps/PA_RoleDesAffaires/FTSByteSe rvingServletImpl?path=941A5ADDCBD2A7967FA717 045881789D441DD9A03654CB056EB4C1BD77207A D3A680CD9F7B06B38FF5BDE9B7845E2E09 \$20CD 81147AB6C983B2B378482C9F6417;

https://www.coindesk.com/luxembourg-passes-bill-togive-blockchain-securities-legal-status

[7] H.R. 2281 Digital Millennium Copyright Act. URL: https://www.congress.gov/bill/105th-congress/housebill/2281/text/enr

[8] A.I. Ovchinnikov, Law and Digital Economy: Main Areas of Cooperation, Philosophy of Law, 3(86) (2018)

[9] B. Casey, Robot Ipsa Loquitur, Georgetown Law Journal, 2019. URL: https://ssrn.com/abstract=3327673

[10] D. Zetzsche, Ch. Preiner, Cross-Border Crowdfunding: Towards a Single Crowdlending and Crowdinvesting Market for Europe, European Business Organization Law Review, 19(2) (2018)
[4] Loi n 2004-575 du 21 juin 2004 pour la confiance dans l'économie numérique (1). URL:https://beta.legifrance.gouv.fr/loda/texte_lc/LEGI TEXT000005789847/ 
[11] L. Hornuf, A. Schwienbacher, Crowdinvesting: Angel Investing for the Masses? Handbook of Research on Business Angels, 2016

[12] V. Salomon, Strategies of Startup Evaluation on Crowdinvesting Platforms: The Case of Switzerland, J. Innovation Economics \& Management, 26 (2018)

[13] V. Salomon, Emergent Models of Financial Intermediation for Innovative Companies: From Venture Capital to Crowdinvesting Platforms in Switzerland,Venture Capital, vol. 18(1) (2016)

[14] V.A. Vaipan, Legal regulation of the digital economy, Entrepreneurial law, Annex "Law and Business", 1 (2018) 12

[15] V.D. Zorkin, Right in the Digital World. Reflection on the margins of the International Legal Forum, Rossiyskaya Gazeta - Stolichny vypusk, May 29, (2018) N 7578 (115)

[16] M.V. Zhabotinsky, Digital rights as objects of civil law rights: concept and emergence of legal regulation, Legal Network Electronic Scientific J., 1(8) (2019)

[17] On Amending Parts One, Two, and Article 1124 of Part Three of the Civil Code of the Russian Federation: Federal Law of March 18, 2019 N 34-FZ, Russian Federation Code. 25.03.2019, N 12, Art. 1224

[18] Civil Code of the Russian Federation (Part One) of November 30, 1994. N 51-FZ [Rev. of 16.12.2019], Russian Federation Code, N 32, Art. 3301, 1994

[19] On Attracting Investments Using Investment Platforms and On Amending Certain Legislative Instruments of the Russian Federation: Federal Law of August 2, 2019 N 259-FZ, Russian Federation Code, 05.08.2019, N 31, Art. 4418

[20] On Digital Financial Assets: Draft Federal Law of March 20, 2018 N 419059-7. URL: http: // sozd.parliament.gov.ru/bil/419059-7

[21] L.Yu. Vasilevskaya, Token as a new subject of civil rights: problems of the legal qualification of digital law, Actual issues of the Russian law, 5(102) (2019)

[22] Civil Code of the Russian Federation (Part Two) of January 26, 1996. N 14-FZ [Rev. of 18.03.2019, as amend. 03.07.2019], Russian Federation Code, N. 5 Art. 410, 1996

[23] On the Strategy for the Development of the Information Society in the Russian Federation for
2017-2030: RF Presidential Decree of May 9, 2017 N 203, Russian Federation Code, N 20 Art. 2901, 2017 